\title{
Meta-analysis
}

\section{Impact of maternal supplementation with probiotics during pregnancy on atopic eczema in childhood - a meta-analysis}

\author{
Katja Doege ${ }^{1}$, Donata Grajecki ${ }^{1}$, Birgit-Christiane Zyriax $^{2}$, Elena Detinkina ${ }^{1}$, Christine zu Eulenburg ${ }^{3}$ \\ and Kai J. Buhling ${ }^{1 *}$ \\ ${ }^{1}$ Department of Gynecology, Universitätsklinikum Hamburg-Eppendorf, Martinistraße 52, 20246 Hamburg, Germany \\ ${ }^{2}$ Department of Endocrinology of Aging, Universitätsklinikum Hamburg-Eppendorf, Martinistraße 52, 20246 Hamburg, \\ Germany \\ ${ }^{3}$ Institute of Medical Biometry and Epidemiology, Universitätsklinikum Hamburg-Eppendorf, Martinistraße 52, 20246 \\ Hamburg, Germany
}

(Received 17 January 2011 - Revised 16 May 2011 - Accepted 20 May 2011 - First published online 26 July 2011)

\section{Abstract}

In the present study, we sought to conduct a literature review of randomised, double-blind, placebo-controlled trials, which assessed the impact of probiotics intake during pregnancy on the development of eczema in children. A meta-analysis was conducted for comparison of the development of atopic eczema in children whose mothers took probiotics during pregnancy $v$. placebo. Study selection, quality appraisal and data extraction were performed independently and in duplicate. The studies were rated according to their size in order to calculate the influence of individual studies on the meta-analysis. A total of seven randomised, double-blind, placebo-controlled trials, published between 2001 and 2009, were selected from the PubMed and Ovid databases for the meta-analysis. The meta-analysis was performed with statistical software Stata/SE11.0. The completed meta-analysis of the seven studies shows a significant risk reduction for atopic eczema in children aged $2-7$ years by the administration of probiotics during pregnancy (reduction $5.7 \%$; $P=0.022$ ). However, this effect was only significant for lactobacilli (reduction $10 \cdot 6 \% ; P=0 \cdot 045$ ), but not for a mixture of various bacterial strains as probiotics (difference $3.06 \%, P=0.204$ ). In conclusion, the meta-analysis shows that the administration of lactobacilli during pregnancy prevents atopic eczema in children aged from 2 to 7 years. However, a mixture of various bacterial strains does not affect the development of atopic eczema, independent of whether they contain lactobacilli or not.

Key words: Atopic dermatitis: Prevention: Probiotics: Meta-analysis: Pregnancy

Atopic dermatitis belongs to the category of atopic diseases and has a prevalence of $10-20 \%$, one of the most frequent primary manifestation of atopy in children (10-20\%). Atopy is a chronic or chronically recurrent inflammatory skin disease, with concomitant severe pruritus. Children, whose both parents suffer from atopic eczema, have a risk of $60-80 \%$ of developing the disease themselves. Polygenic inheritance is assumed, in which genomic imprinting and various environmental factors also seem to play a role ${ }^{(1)}$.

The prevalence of atopic diseases, and especially atopic eczema, has increased over the past years ${ }^{(2)}$. There are various hypotheses explaining the increasing prevalence of the allergies. One of these hypotheses is the 'linoleic acid hypothesis'. It claims that a possible explanation lies in the choice of dietary fats as well as the modified composition of the dietary fats in food ${ }^{(3)}$. A further hypothesis is the 'hygiene hypothesis', which argues that the missing infections at a critical time point in the development of the immune system increase the risks for later allergic diseases ${ }^{(4)}$. Various other hypotheses also try to explain the increasing prevalence. However, the cause remains unknown.

Therapy consists of expositional prophylaxis and the administration of glucocorticoids, calcineurin inhibitors and cyclosporine A. Additionally, specific immunotherapy can be performed $^{(5)}$. Furthermore, in order to avoid atopic diseases, it is recommended to breastfeed 6 months after delivery, avoid passive smoking and protect the child from house dust mites ${ }^{(2)}$.

Probiotics are preparations that contain living microorganisms, i.e. lactic acid bacteria and yeasts. They may be 
contained within food or as pharmaceuticals. When ingested in sufficient quantities orally, probiotics may have a healthpromoting influence in obstruction, diarrhoea, chronic inflammatory bowel syndrome and other diseases ${ }^{(6-8)}$.

Some clinical trials confirm that the administration of probiotics already during pregnancy and within the first months of life may reduce the risk for atopic dermatitis ${ }^{(9,10)}$, whereas other studies ${ }^{(11)}$ could not show this effect. The gastrointestinal tract of healthy fetuses is sterile. Only during delivery and in the time following, the mother's bacteria colonise the intestine of the fetus and develop into a complex microflora. If probiotics, for example, the Lactobacillus rhamnosus strain GG, are taken during pregnancy, they form part of the mother's gut flora and are thus also transferred to the child. In contrast to the mother, where L. rhamnosus strain GG only remains for a short time after the discontinuation of intake, they remain detectable in the child's stool for another 6 months after delivery and the discontinuation of intake ${ }^{(12)}$.

The safety of the intake of probiotics during pregnancy has been well tested, especially for lactobacilli and bifidobacteria. It is considered to be well tolerated and has a low risk of side effects ${ }^{(13,14)}$.

In the present study, we sought to conduct a systematic review of randomised trials involving the use of probiotics given during pregnancy and the incidence of atopic eczema in children.

\section{Materials and methods}

The present study is based on a systematic database research for randomised, controlled studies on probiotic administration during pregnancy and the risk of atopic eczema within the first years of life.

The following databases were searched starting from the respective start of the database up to and including 23 June 2009. The search terms were 'pregnancy and probiotics':
(1) PubMed

(2) Ovid

(a) EBM Reviews - Cochrane Central Register of Controlled Trials

(b) EBM Reviews - Cochrane Database of Systematic Reviews

(c) EBM Reviews - Cochrane Methodology Register

(d) EMBASE 1980 until 23 June 2009

(e) Ovid Medline(r) 1950 until 23 June 2009

Subsequently, the references in the publications were searched for additional, potentially important, publications (Fig. 1). Only publications with ethics approval were included.

Data collection was performed by two independent reviewers while adhering to a data collection sheet. The analyses were then compared and possible discrepancies were solved with the help of a third reviewer (Table 1).

On the basis of the data collection sheets as well as the original articles, quality assessment was made (Table 2). This was done according to the 'CRD's guidance for undertaking reviews in health care' written by the Centre for Reviews and Dissemination. Data that were not found in the original publications could not be considered in the evaluation. An overview of the individual study results is provided in Table 3 .

The available data were compared with the statistical software Stata/SE 11.0 (StataCorp LP, College Station, TX, USA). It calculated the risk ratio for each study endpoint as well as the respective $95 \%$ CI. In addition, the studies were rated according to their size in order to calculate the influence of individual studies on the meta-analysis. With heterogeneity testing, the comparability of the data that were analysed was assessed.

\section{Results}

A total of seven systematic randomised, double-blind and placebo-controlled studies observing 2843 children whose mothers took probiotics or placebo during pregnancy and

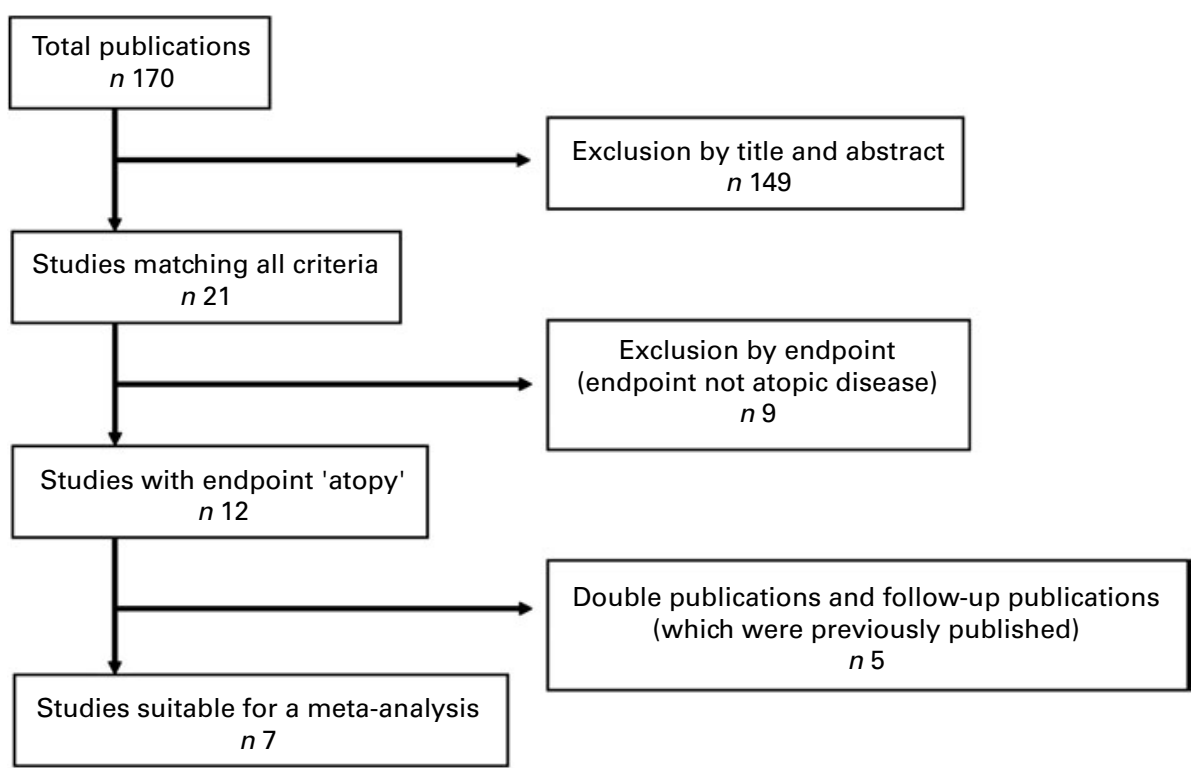

Fig. 1. Study selection. 
Table 1. Major contents of the studies on probiotics

\begin{tabular}{|c|c|c|c|c|c|c|c|c|c|}
\hline Author (year) & $\begin{array}{l}\text { Primary } \\
\text { objective }\end{array}$ & $\begin{array}{l}\text { Secondary } \\
\text { objective }\end{array}$ & $n$ & Male (\%) & $\begin{array}{l}\text { Comparable } \\
\text { groups }\end{array}$ & $\begin{array}{l}\text { Probiotic (colony- } \\
\text { forming units) }\end{array}$ & Placebo & $\begin{array}{l}\text { Intake } \\
\text { from/until }\end{array}$ & Results \\
\hline $\begin{array}{l}\text { Kuitunen et al. } \\
(2009)^{(15)}\end{array}$ & $\begin{array}{l}\text { Allergy, } \\
\text { atopic } \\
\text { eczema }\end{array}$ & $\begin{array}{l}\text { Eczema, allergic } \\
\text { rhinitis, asthma, } \\
\text { food allergy } \\
\text { and IgE } \\
\text { sensitisation }\end{array}$ & 891 & $49 \cdot 5$ & Yes & $\begin{array}{l}\text { Lactobacillus GG }\left(5 \times 10^{9}\right) \text {, } \\
\text { L. rhamnosus LC705 } \\
\left(5 \times 10^{9}\right), \text { Bifidobacterium } \\
\text { breve Bb99 }\left(2 \times 10^{9}\right) \text { and } \\
\text { Propionibacterium } \\
\text { freudenreichii ssp. } \\
\text { Shermanii }\left(2 \times 10^{9}\right)\end{array}$ & $\begin{array}{l}\text { Same appearance, } \\
\text { taste, smell } \\
\text { and intake }\end{array}$ & $\begin{array}{l}\text { 36th week } \\
\text { of gestation } \\
\text { until } 6 \text { months } \\
\text { after birth }\end{array}$ & $\begin{array}{l}\text { No allergy prevention } \\
\text { and less asthma } \\
\text { in children with } \\
\text { caesarean sections }\end{array}$ \\
\hline $\begin{array}{l}\text { Wickens et al. } \\
\qquad(2008)^{(16)}\end{array}$ & $\begin{array}{l}\text { Eczema } \\
\text { and atopic } \\
\text { eczema }\end{array}$ & $\begin{array}{l}\text { Characteristics } \\
\text { of eczemas and } \\
\text { detection of } \\
\text { bacteria in stool }\end{array}$ & 446 & $51 \cdot 9$ & Yes & $\begin{array}{l}\text { Group 1: L. rhamnosus } \\
\text { HNO01 }\left(6 \times 10^{9}\right) \\
\text { Group 2: B. animalis ssp. } \\
\text { lactis HN019 }\left(9 \times 10^{9}\right)\end{array}$ & $\begin{array}{l}\text { Same appearance, } \\
\text { taste, smell } \\
\text { and intake }\end{array}$ & $\begin{array}{l}\text { 25th week of } \\
\text { pregnancy } \\
\text { until } 2 \text { years } \\
\text { after birth }\end{array}$ & $\begin{array}{l}\text { Eczemas were reduced } \\
\text { by the intake of } \\
\text { L. rhamnosus }\end{array}$ \\
\hline $\begin{array}{l}\text { Hurree et al. } \\
\qquad(2008)^{(17)}\end{array}$ & $\begin{array}{l}\text { Allergic } \\
\text { diseases }\end{array}$ & $\begin{array}{l}\text { Cytokine } \\
\text { concentration } \\
\text { of breast milk }\end{array}$ & 140 & NS & Yes & $\begin{array}{l}\text { L. rhamnosus } \mathrm{GG} \text { and } \\
\text { Bifidobacterium I actis } \\
\text { Bb12 }\left(1 \times 10^{10}\right)\end{array}$ & NS & $\begin{array}{l}\text { First trimester } \\
\text { until the end } \\
\text { of exclusive } \\
\text { lactation }\end{array}$ & $\begin{array}{l}\text { Allergy risk can be } \\
\text { reduced }\end{array}$ \\
\hline $\begin{array}{l}\text { Kopp et al. } \\
\qquad(2008)^{(18)}\end{array}$ & $\begin{array}{l}\text { Atopic } \\
\text { dermatitis }\end{array}$ & $\begin{array}{l}\text { Bronchitis and } \\
\text { allergies }\end{array}$ & 94 & $44 \cdot 7$ & Yes & Lactobacillus GG $\left(5 \times 10^{9}\right)$ & $\begin{array}{l}\text { Same appearance, } \\
\text { taste, smell, } \\
\text { intake and } \\
\text { packing }\end{array}$ & $\begin{array}{l}4-6 \text { weeks } \\
\text { before } \\
\text { birth until } \\
3 \text { months } \\
\text { after birth }\end{array}$ & $\begin{array}{l}\text { No differences in atopic } \\
\text { dermatitis and } \\
\text { reactions to inhalative } \\
\text { allergens, recurrent } \\
\text { bronchitis in the } \\
\text { Lactobacillus } \\
\text { GG group }\end{array}$ \\
\hline $\begin{array}{l}\text { Abrahamsson } \\
\text { et al. }(2007)^{(9)}\end{array}$ & $\begin{array}{l}\text { Allergic } \\
\text { diseases }\end{array}$ & - & 188 & 52 & Yes & L. reuteri $\left(1 \times 10^{8}\right)$ & $\begin{array}{l}\text { Same appearance, } \\
\text { taste, smell } \\
\text { and intake }\end{array}$ & $\begin{array}{l}\text { 36th week of } \\
\text { pregnancy } \\
\text { until } 12 \text { months } \\
\text { after birth }\end{array}$ & $\begin{array}{l}\text { Less IgE-associated } \\
\text { eczema and less } \\
\text { asthma }\end{array}$ \\
\hline $\begin{array}{l}\text { Kukkonen et al. } \\
\qquad(2007)^{(19)}\end{array}$ & $\begin{array}{l}\text { Allergic } \\
\text { diseases, } \\
\text { lgE } \\
\text { sensitisation }\end{array}$ & Eczema & 925 & $49 \cdot 5$ & Yes & $\begin{array}{l}\text { Lactobacillus GG }\left(5 \times 10^{9}\right) \text {, } \\
\text { L. rhamnosus }\left(5 \times 10^{9}\right) \text {, } \\
\text { Bifidobacterium } \\
\text { breve }\left(2 \times 10^{8}\right) \text {, } \\
\text { Propionibacterium } \\
\text { freudenreichii ssp. } \\
\text { Shermanii }\left(2 \times 10^{9}\right)\end{array}$ & $\begin{array}{l}\text { Same appearance, } \\
\text { taste, smell } \\
\text { and intake }\end{array}$ & $\begin{array}{l}2-4 \text { weeks } \\
\text { before birth } \\
\text { and until } \\
6 \text { months } \\
\text { after birth }\end{array}$ & $\begin{array}{l}\text { Less eczema and same } \\
\text { prevalence of } \\
\text { allergies }\end{array}$ \\
\hline $\begin{array}{l}\text { Kalliomäki et al. } \\
(2007)^{(10)}, \\
\text { Kalliomäki } \\
(2001,2003)\end{array}$ & $\begin{array}{l}\text { Atopic } \\
\text { eczema }\end{array}$ & $\begin{array}{l}\text { Allergic rhinitis } \\
\text { and asthma }\end{array}$ & 159 & $50 \cdot 5$ & Yes & Lactobacillus $\mathrm{GG}\left(1 \times 10^{10}\right)$ & $\begin{array}{l}\text { Same appearance, } \\
\text { taste, smell } \\
\text { and intake }\end{array}$ & $\begin{array}{l}2-4 \text { weeks } \\
\text { before birth } \\
\text { until } 6 \text { months } \\
\text { after birth }\end{array}$ & $\begin{array}{l}\text { Less eczemas and a } \\
\text { little more asthma }\end{array}$ \\
\hline
\end{tabular}


Table 2. Summary of quality criteria

\begin{tabular}{|c|c|c|c|c|c|c|c|}
\hline Study & $\begin{array}{l}\text { Kuitunen et al. } \\
\qquad(2009)^{(15)}\end{array}$ & $\begin{array}{l}\text { Wickens et al. } \\
(2008)^{(16)}\end{array}$ & $\begin{array}{l}\text { Hurree et al. } \\
\qquad(2008)^{(17)}\end{array}$ & $\begin{array}{l}\text { Kopp et al. } \\
(2008)^{(18)}\end{array}$ & $\begin{array}{l}\text { Abrahamsson et al. } \\
\qquad(2007)^{(9)}\end{array}$ & $\begin{array}{l}\text { Kukkonen et al. } \\
\qquad(2007)^{(19)}\end{array}$ & $\begin{array}{c}\text { Kalliomäki et al. } \\
(2007)^{(10)} \text {, Kalliomäki } \\
(2001,2003)\end{array}$ \\
\hline Randomised & Yes & Yes & Yes & Yes & Yes & Yes & Yes \\
\hline Randomisation method described in detail & No & Yes & No & No & No & Yes & Yes \\
\hline Double-blinded & Yes & Yes & Yes & Yes & Yes & Yes & Yes \\
\hline Placebo controlled & Yes & Yes & Yes & Yes & Yes & Yes & Yes \\
\hline Identical appearance of verum and placebo & Yes & Yes & NS & Yes & Yes & Yes & Yes \\
\hline Analysis blinded & Yes & Yes & NS & NS & NS & NS & Yes \\
\hline Inclusion and exclusion criteria listed & Yes & Yes & Yes & Yes & Yes & Yes & Yes \\
\hline Comparability of the groups present & Yes & Yes & Yes & Yes & Yes & Yes & Yes \\
\hline All drop-outs described & Yes & Yes & No & Yes & Yes & Yes & No \\
\hline
\end{tabular}

Table 3. Mentioned frequencies, $\mathrm{OR}, \mathrm{Cl}$ and $P$ values in the studies

\begin{tabular}{|c|c|c|c|c|c|c|}
\hline Study & Endpoint & $\begin{array}{l}\text { Prevalence in probiotics } \\
\text { group }(\%)\end{array}$ & $\begin{array}{c}\text { Prevalence in placebo } \\
\text { group (\%) }\end{array}$ & OR & $95 \% \mathrm{Cl}$ & $P$ \\
\hline $\begin{array}{l}\text { Kuitunen et al. (2009) })^{(15)} \\
\text { Wickens et al. }(2008)^{(16)}\end{array}$ & Atopic eczema & $24 \cdot 0$ & $25 \cdot 1$ & 0.94 & $0 \cdot 70,1 \cdot 28$ & 0.711 \\
\hline Lactobacillus rhamnosus & Atopic eczema & 9.9 & 18.5 & 0.51 & $0.27,0.97$ & 0.04 \\
\hline Bifidobacterium animalis & Atopic eczema & $12 \cdot 8$ & 18.5 & 0.69 & $0.38,1.24$ & 0.04 \\
\hline Hurree et al. $(2008)^{(17)}$ & Atopic eczema & $9 \cdot 7$ & $17 \cdot 6$ & & & 0.131 \\
\hline Kopp et al. $(2008)^{(18)}$ & Atopic eczema & 28 & $27 \cdot 3$ & 0.96 & $0.38,2.33$ & 0.93 \\
\hline Abrahamsson et al. $(2007)^{(9)}$ & Atopic eczema & 17 & 28 & & & \\
\hline Kukkonen et al. $(2007)^{(19)^{\prime}}$ & Atopic eczema & $12 \cdot 4$ & $17 \cdot 7$ & 0.66 & $0.46,0.95$ & 0.025 \\
\hline Kalliomäki et al. $(2007)^{(10)}$ & $\begin{array}{l}\text { Atopic eczema } \\
\quad \text { (after } 2 \text { years) }\end{array}$ & 23 & 46 & 0.51 & $0.32,0.84$ & 0.008 \\
\hline Kalliomäki et al. (2001) & $\begin{array}{l}\text { Atopic eczema } \\
\quad \text { (after } 4 \text { years) }\end{array}$ & $26 \cdot 4$ & $46 \cdot 3$ & $0.57(\mathrm{RR})$ & $0.33,0.97$ & \\
\hline Kalliomäki et al. (2003) & $\begin{array}{l}\text { Atopic eczema } \\
\text { (after } 7 \text { years) }\end{array}$ & $42 \cdot 6$ & $66 \cdot 1$ & 0.58 & $0.35,0.94$ & 0.027 \\
\hline
\end{tabular}

$\mathrm{RR}$, risk ratio. 


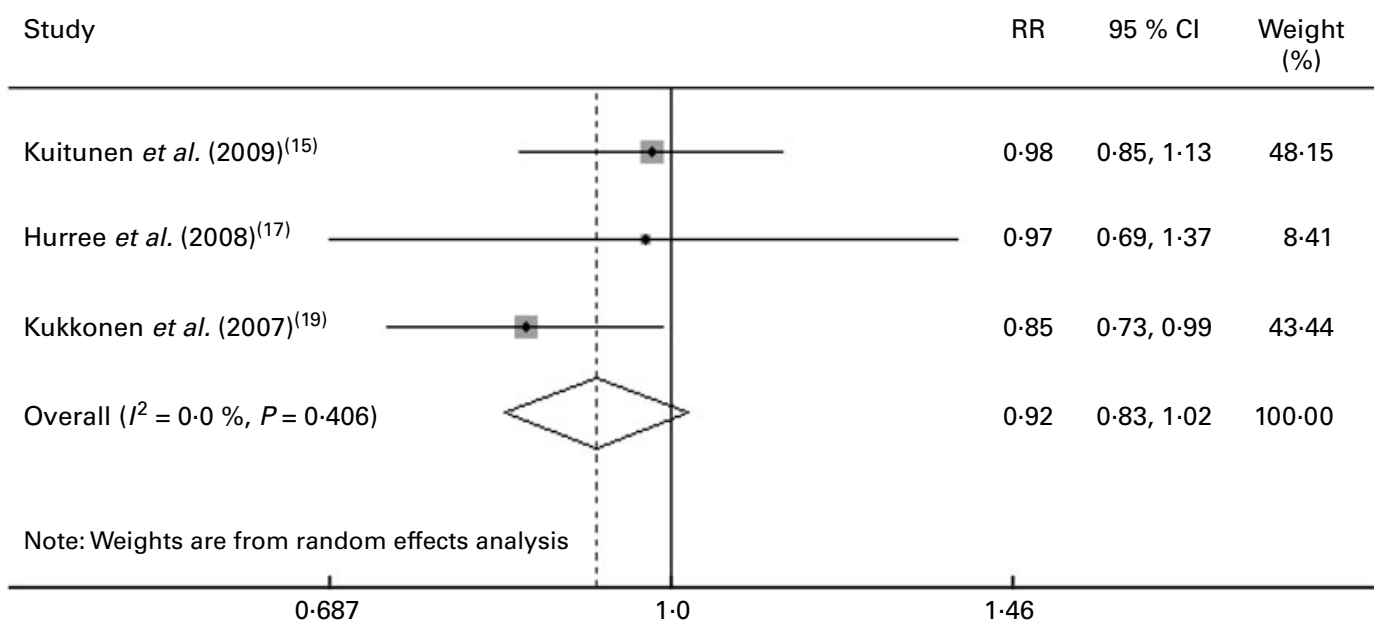

Fig. 2. Endpoint analysis of studies that used mixed probiotics and the development of atopic eczema. RR, risk ratio.

lactation were included in the meta-analysis. All studies that were included used atopic eczema as an endpoint.

Of those studies, four only used lactobacilli as probiotics, three used a mixture of various bacterial strains (including lactobacilli) and one included bifidobacteria.

On the basis of the selected studies, two meta-analyses were performed. It was observed that one study used lactobacilli and the other studies used a mixture of bacterial strains.

The meta-analysis on those studies that used a mixture of various bacterial strains shows no significant association between the intake during pregnancy and lactation and the development of atopic eczema in the children $(P=0 \cdot 204)$. The study by Kuitunen et al. ${ }^{(15)}$ showed the strongest contribution to the meta-analysis (Fig. 2).

The meta-analysis on the studies that used only lactobacilli as probiotics shows a significant correlation between the administration of the probiotics during pregnancy and lactation and the development of atopic eczema ( $P=0.045$, Fig. 3). All the studies that are included contribute equally to the meta-analysis.

\section{Discussion}

Overall, probiotics significantly reduce the risk of the development of atopic eczema $(P=0 \cdot 022)$. However, the effect can only be ascribed to the results of three of the seven studies.

In a separate analysis of the studies that used lactobacilli and those that used a bacterial strain mixture, only monotherapy resulted in a significant risk reduction for atopic eczema ( $P=0.045$ v. $P=0.204$ ). Surprisingly, the bacterial load per bacterial strain is comparable in the strain mixture and monotherapy. However, it may be possible that the orally applied bacteria remain in the gut for only a short time due to displacement effects. A possible reason could be a repression of each other, which anticipates the attainment of effective concentrations.

There is some evidence that probiotics maintain the integrity of the intestinal barrier. Some of the effects appear to be mediated through Toll-like receptors, which are also expressed by the enterocytes ${ }^{(20)}$. But this effect is limited only to some species (Lactobacillus reuteri and Lactobacillus casei) and not to others (Lactobacillus planarum).

\begin{tabular}{|c|c|c|c|}
\hline Study & $\mathrm{RR}$ & $95 \% \mathrm{Cl}$ & $\begin{array}{c}\text { Weight } \\
(\%)\end{array}$ \\
\hline Wickens et al. $(2008)^{(16)}$ & 0.77 & $0.60,0.99$ & 33.56 \\
\hline Kopp et al. $(2008)^{(18)}$ & 1.01 & $0.64,1.62$ & $9 \cdot 43$ \\
\hline Abrahamsson et al. (2007) ${ }^{(9)}$ & 0.80 & $0.59,1.08$ & $22 \cdot 73$ \\
\hline Kalliomäki et al. $(2007)^{(10)}$ & 0.84 & $0.66,1.07$ & $34 \cdot 28$ \\
\hline Overall $\left(I^{2}=0.0 \%, P=0.777\right)$ & 0.82 & $0.71,0.95$ & $100 \cdot 00$ \\
\hline Note: Weights are from random effects analysis & & & \\
\hline 0.593 & 1.69 & & \\
\hline
\end{tabular}

Fig. 3. Endpoint analysis of studies that used lactobacilli and the development of atopic eczema. RR, risk ratio. 
The reason for the different effects might be that those species cannot bind the three grabbing non-integrin molecules that are blocking the antibodies that are responsible for intercellular adhesion molecule. On the basis of available data, the recommendation for the administration of probiotics consisting of lactobacilli during pregnancy and lactation can be made, as it may lead to a reduction in the development of atopic eczema in children at risk. More longitudinal studies observing the clinical and experimental factors as well as the time of the beginning such a therapy are necessary ${ }^{(21)}$.

This effect could not be found in the actual S-3 guidelines from the German Society of Dermatology since two of the publications cited were published after the literature research in March $2008^{(22)}$.

Due to non-significant results, no recommendation for probiotics consisting of different bacterial strains can be given. No evidence-based studies are currently available on other probiotics.

The severity of atopic eczema was less in the group that received L. rhamnosus than in the group that took Bifidobacterium animalis spp. lactis ${ }^{(16)}$.

In conclusion, probiotics, especially lactobacilli, reduce when taken as a monotherapy during pregnancy the child's risk of developing atopic eczema. The long-term development of this effect will have to be assessed in further studies, and so do the possibly differing effects of single bacterial strains.

\section{Acknowledgements}

The authors declare no conflict of interest. The study was not funded. The contribution of each author to the manuscript is as follows: K. D. planned the review protocol and performed the review process; D. G. planned the review protocol and advised on the review process; B.-C. Z. planned the review protocol regarding the nutritional facts and advised the manuscript on nutritional facts; E. D. performed the review process; C. z. E. advised on the statistics; K. J. B. advised on all aspects of planning, performing and appraising of the study. All authors approved the final version.

\section{References}

1. Burgdorf WHC, Plewig G \& Wolff HH (2008) Braun-Falco's Dermatology, 3rd ed. Berlin: Springer.

2. Biedermann $\mathrm{T} \&$ Piche E (2006) Atopic dermatitis (AD). CME Dermatology 1, 4-19.

3. Galland L (1986) Increased requirements for essential fatty acids in atopic individuals: a review with clinical descriptions. J Am Coll Nutr 5, 213-228.

4. Cabana MD, Michael D, Wong AR, et al. (2007) Examining the hygiene hypothesis: the trial of Infant Probiotic Supplementation. Paediatr Perinat Epidemiol 21, 23-28.

5. Werfel $\mathrm{T}$ et al. (2008) S3-Guidline Neurodermitis. http:// www.awmf.org/uploads/tx_szleitlinien/013-0271_S2e_Neuro dermitis_01.pdf

6. Bernaola Aponte G, Bada Mancilla CA, Carreazo Pariasca NY, et al. (2010) Probiotics for treating persistent diarrhoea in children. The Cochrane Database of Systematic Reviews Issue 11, CD007401.

7. Sazawal S, Hiremath G, Dhingra U, et al. (2006) Efficacy of probiotics in prevention of acute diarrhoea: a meta-analysis of masked, randomised, placebo-controlled trials. Lancet Infect Dis 6, 374-382.

8. Haller D, Antoine JM, Bengmark S, et al. (2010) Guidance for substantiating the evidence for beneficial effects of probiotics: probiotics in chronic inflammatory bowel disease and the functional disorder irritable bowel syndrome. $J$ Nutr 140, 690S-697S (Review).

9. Abrahamsson TR, Jakobsson T, Böttcher MF, et al. (2007) Probiotics in prevention of IgE-associated eczema: a double-blind, randomized, placebo-controlled trial. J Allergy Clin Immunol 119, 1174-1180.

10. Kalliomäki M, Salminen S, Poussa T, et al. (2007) Probiotics during the first 7 years of life: a cumulative risk reduction ofs eczema in a randomised, placebo-controlled trial. $J$ Allergy Clin Immunol 119, 1019-1021.

11. Kopp MV \& Salfeld P (2009) Probiotics and prevention of allergic disease. Curr Opin Clin Nutr Metab Care 12, 298-303.

12. Schultz M, Göttl C, Young RJ, et al. (2004) Administration of oral probiotic bacteria to pregnant women causes temporary infantile colonization. J Pediatr Gastroenterol Nutr 38, 293-297.

13. Borriello SP, Hammes WP, Holzapfel W, et al. (2003) Safety of probiotics that contain lactobacilli or bifidobacteria. Clin Infect Dis 36, 775-780.

14. Dugoua JJ, Machado M, Zhu X, et al. (2009) Probiotic safety in pregnancy: a systematic rewiew and meta-analysis of randomized controlled trials of Lactobacillus, Bifidobacterium and Saccharomyces spp. J Obstet Gynaecol Can 31, 542-552.

15. Kuitunen $\mathrm{M}$, Kukkonen $\mathrm{K}$, Juntunen-Backmann $\mathrm{K}$, et al. (2009) Probiotics prevent IgE-associated allergy until age 5 years in cesarean-delivered children but not in the total cohort. J Allergy Clin Immunol 123, 335-341.

16. Wickens K, Black PN, Stanley TV, et al. (2008) A differential effect of 2 probiotics in the prevention of eczema and atopy: a double-blind, randomized, placebo-controlled trial. J Allergy Clin Immunol 122, 788-794.

17. Hurree A, Laitinen K, Rautava S, et al. (2008) Impact of maternal atopy and probiotic supplementation during pregnancy on infant sensitizations: a double-blind, placebocontrolled study. Clin Exp Allergy 38, 1342-1348.

18. Kopp MV, Hennemuth I \& Heinzmann A (2008) Randomized, double-blind, placebo-controlled trial of probiotics for primary prevention: no clinical effects of Lactobacillus GG supplementation. Pediatrics 121, e850-e856.

19. Kukkonen K, Savilahti E, Haahtela T, et al. (2007) Probiotics and prebiotic galacto-oligosaccharides in the prevention of allergic diseases: a randomized, double-blind, placebocontrolled trial. J Allergy Clin Immunol 119, 192-198.

20. Rachmilewitz D, Katakura K, Karmeli F, et al. (2004) Toll-like receptor 9 signaling mediates the anti-inflammatory effects of probiotics in murine experimental colitis. Gastroenterology 126, 520-528.

21. Prescott SL \& Bjorksten B (2007) Probiotics for the prevention or treatmentof allergic diseases. J Allergy Clin Immunol 120, 255-262.

22. Schäfer T (2009) S-3-Leitlinie Allergieprävention. http:// www.awmf.org/uploads/tx_szleitlinien/061-016_S3_Allergie praevention_03-2009_03-2014.pdf

23. Kalliomäki $\bar{M}$, Salminen S, Arvilommi H, et al. (2001) Probiotics in primary prevention of atopic disease: a randomised, placebo-controlled trial. Lancet 357, 1076-1079.

24. Kalliomäki M, Salminen S, Poussa T, et al. (2003) Probiotics and prevention of atopic disease: 4-years follow-up of a randomised placebo-controlled trial. Lancet 361, 1869-1871. 